\title{
Indicators of Antarctic ozone depletion: 1979 to 2019
}

\author{
Greg E. Bodeker ${ }^{1,2}$ and Stefanie Kremser ${ }^{1}$ \\ ${ }^{1}$ Bodeker Scientific, 42 Russell Street, Alexandra, 9320, New Zealand \\ ${ }^{2}$ School of Geography, Environment and Earth Sciences, Victoria University of Wellington, Wellington, New Zealand
}

Correspondence: G. E. Bodeker (greg@ bodekerscientific.com)

Received: 20 October 2020 - Discussion started: 17 November 2020

Revised: 19 February 2021 - Accepted: 24 February 2021 - Published: 6 April 2021

\begin{abstract}
The National Institute of Water and Atmospheric Research/Bodeker Scientific (NIWA-BS) total column ozone (TCO) database and the associated BS-filled TCO database have been updated to cover the period 1979 to 2019, bringing both to version 3.5.1 (V3.5.1). The BSfilled database builds on the NIWA-BS database by using a machine-learning algorithm to fill spatial and temporal data gaps to provide gap-free TCO fields over Antarctica. These filled TCO fields then provide a more complete picture of wintertime changes in the ozone layer over Antarctica. The BS-filled database has been used to calculate continuous, homogeneous time series of indicators of Antarctic ozone depletion from 1979 to 2019 , including (i) daily values of the ozone mass deficit based on TCO below a 220 DU threshold; (ii) daily measures of the area over Antarctica where TCO levels are below $150 \mathrm{DU}$, below $220 \mathrm{DU}$, more than $30 \%$ below 1979 to 1981 climatological means, and more than $50 \%$ below 1979 to 1981 climatological means; (iii) the date of disappearance of 150 DU TCO values, 220 DU TCO values, values $30 \%$ or more below 1979 to 1981 climatological means, and values $50 \%$ or more below 1979 to 1981 climatological means, for each year; and (iv) daily minimum TCO values over the range 75 to $90^{\circ} \mathrm{S}$ equivalent latitude. Since both the NIWA-BS and BS-filled databases provide uncertainties on every TCO value, the Antarctic ozone depletion metrics are provided, for the first time, with fully traceable uncertainties. To gain insight into how the vertical distribution of ozone over Antarctica has changed over the past 36 years, ozone concentrations, combined and homogenized from several satellite-based ozone monitoring instruments as well as the global ozonesonde network, were also analysed. A robust attribution to changes in the drivers of long-term secular variability in these metrics has not been performed in this analysis. As a result, statements about the recovery
\end{abstract}

of Antarctic TCO from the effects of ozone-depleting substances cannot be made. That said, there are clear indications of a change in trend in many of the metrics reported on here around the turn of the century, close to when Antarctic stratospheric concentrations of chlorine and bromine peaked.

\section{Introduction}

The Antarctic ozone hole, discovered in the mid-1980s (Farman et al., 1985), is perhaps the best known manifestation of the impacts of ozone-depleting substances (ODSs) on the global ozone layer. The primary role of ODSs as the cause of Antarctic ozone destruction has been firmly established on a body of evidence including laboratory measurements, atmospheric observations, and modelling studies (Newman et al., 2009). The Montreal Protocol, enacted in 1987, with subsequent amendments and adjustments, committed countries to significantly reduce their production of ODSs. The Montreal Protocol has been labelled as one of the most successful global environmental treaties (Gonzalez et al., 2015; McKenzie et al., 2019). The reduction in stratospheric chlorine and bromine loading resulting from compliance with the Montreal Protocol is expected to lead to a recovery of ozone from the effects of ODSs in many regions of the atmosphere (e.g. Yang et al., 2008; Kuttippurath, 2013; Solomon et al., 2016). Nevertheless, an ozone hole continues to appear over Antarctica in each austral spring (Douglass et al., 2011). Projections of the future evolution of the ozone layer over Antarctica using coupled chemistry-climate models suggest that with continued compliance with the Montreal Protocol, the ozone layer over Antarctica is expected to return to 1980 levels around 2060 (Dhomse et al., 2018; Amos et al., 2020). 
Three metrics commonly used to define the Antarctic ozone hole are the area of the hole (adding the areas of cells falling below some threshold in a total column ozone (TCO) field), the minimum TCO value within the hole, and the Antarctic ozone mass deficit (Uchino et al., 1999; Huck et al., 2007). Bodeker et al. (2005) reported on these metrics, using four different criteria for ozone hole type values, viz. (i) TCO below $150 \mathrm{DU}$, (ii) TCO below $220 \mathrm{DU}$, (iii) TCO $30 \%$ or more below the 1979 to 1981 climatological mean, and (iv) TCO $50 \%$ or more below the 1979 to 1981 climatological mean. Time series of these metrics were updated in subsequent publications (Müller et al., 2008; Struthers et al., 2009). Other studies to date have shown that all three metrics show a slowing of Antarctic ozone depletion, consistent with the first stage of ozone recovery from the effects of ODSs (Krzyścin et al., 2005; Keeble et al., 2018) around the turn of the century when equivalent effective Antarctic stratospheric chlorine (EEASC; Newman et al., 2006) maximized.

Interannual variability in Antarctic stratospheric dynamics, manifest most obviously in interannual variability in Antarctic stratospheric temperatures, drives significant interannual variability in the severity of Antarctic ozone depletion (Schoeberl et al., 1996; Newman and Nash , 2000; Newman et al., 2004, 2006). Using TCO measurements from multiple satellite-based instruments, and after accounting for interannual variability in stratospheric temperatures, de Laat et al. (2017) found that ozone mass deficit decreased by $0.77 \pm 0.17 \mathrm{Mtyr}^{-1}(2 \sigma)$ between 2000 and 2015 . More recently, Tully et al. (2019) analysed linear trends in several Antarctic ozone hole metrics over the periods 1979 to 2001 and 2001 to 2017. They considered metrics both with and without an adjustment to account for interannual meteorological variability and found that all metrics they considered showed a trend towards reduced ozone depletion since 2001 at significance levels between 2.4 and 3.9 standard errors of the trend. However, they only used TCO measurements from three satellite instruments, i.e. TOMS, OMI, and OMPS. Furthermore, both de Laat et al. (2017) and Tully et al. (2019) appear not to have homogenized the different data sets used and did not infer missing measurements during the polar night and elsewhere.

This study presents updated time series of metrics of the Antarctic ozone hole calculated from the long-term homogenized National Institute of Water and Atmospheric Research/Bodeker Scientific (NIWA-BS) TCO database and the associated Bodeker Scientific filled (BS-filled) TCO database, described in Sec. 2. It adds to extant literature reporting on the evolution of the Antarctic ozone hole.

\section{Ozone databases}

This paper takes advantage of several features of the new version 3.4 (V3.4) NIWA-BS and BS-filled TCO databases (Bodeker et al., 2020a), updates them to the end of 2019 to create V3.5.1 of the databases, and uses the BS-filled database to define continuous, homogeneous time series of several metrics describing key attributes of the Antarctic ozone hole. The databases are constructed using measurements from 17 different satellite-based instruments wherein offsets and drifts between (i) the ground-based Dobson and Brewer spectrophotometer networks and (ii) a subset of the satellite-based measurements are removed and then used as the basis for homogenizing the remaining TCO data sets. V3.4 and V3.5.1 of the BS-filled TCO databases comprise spatially filled TCO fields that use a machine-learning approach to infer missing data in regions and at times for which measurements were not available (Bodeker et al., 2020a). This approach significantly improves on the "over the pole" method described in Bodeker et al. (2001a) to create far more physically plausible renditions of the ozone fields in regions of missing data. The result is a continuous gap-free database of daily TCO fields at $1.25^{\circ}$ longitude by $1^{\circ}$ latitude resolution.

Unlike previous versions of the database, both V3.4 (1979-2016) and V3.5.1 (1979-2019) include uncertainties traceable to uncertainties in the TCO fields measured by the 17 different space-based instruments that are used to construct the database. To propagate the uncertainties on the TCO fields to uncertainties in the Antarctic ozone depletion metrics, two additional databases were created, one in which the $1 \sigma$ uncertainties were added to each TCO field and another where the $1 \sigma$ uncertainties were subtracted from each TCO field, i.e. assuming uniform overestimation of TCO and underestimation of ozone by $\pm 1 \sigma$. We take this approach of assuming perfect spatial correlation across all uncertainties (i.e. all TCO values biased high and all TCO values biased low) to obtain a conservative estimate of the uncertainties; assuming the uncertainties to be perfectly uncorrelated results in very small uncertainty estimates on the metrics. By calculating the ozone depletion metrics across all three databases, estimates can be obtained for $+1 \sigma$ and $-1 \sigma$ uncertainties on all metric time series.

To demonstrate how the vertical structure of the ozone layer over Antarctica has changed from 1985 to 2019, ozone concentrations were extracted from the Bodeker Scientific vertically resolved ozone database (BSVertOzone, Hassler et al., 2018a) and mapped onto an equivalent latitude $\left(\phi_{\mathrm{eq}}\right)$ coordinate system so that only values well inside the ozone hole ( $\phi_{\text {eq }}$ poleward of $75^{\circ} \mathrm{S}$ ) could be selected. BSVertOzone combines measurements from several satellite-based instruments and ozone profile measurements from the global ozonesonde network to create sparse fields of ozone concentrations on 70 altitude levels from 1 to $70 \mathrm{~km}$. Offsets and drifts between each satellite-based ozone data set and a selected standard (SAGE-II in the stratosphere and ozonesondes in the troposphere) were used to create a single homogeneous database of ozone concentrations. Similar to the TCO database, measurement uncertainties and uncertainties from other sources (e.g. applied offset and bias corrections) are 


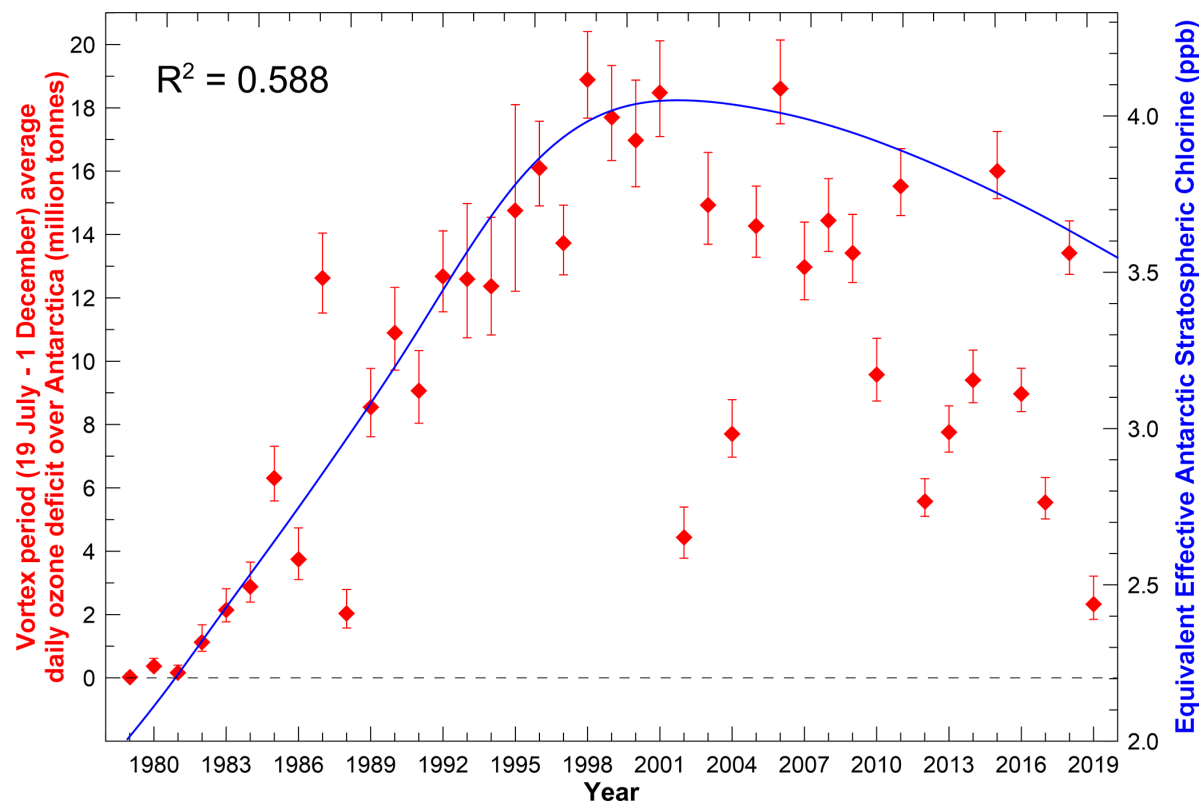

Figure 1. Antarctic vortex period (AVP; day 200 to 335) average daily ozone mass deficit plotted against the left $y$ axis (red) and equivalent effective Antarctic stratospheric chlorine (EEASC) plotted against the right $y$ axis (blue). The $R^{2}$ value shows the correlation coefficient between the two time series over the full period.

propagated through to the final product; i.e. every ozone concentration has an associated uncertainty. The development of the BSVertOzone database is described in detail in Hassler et al. (2018a). For this study, the database was extended to cover the period 1979 to 2019.

\section{Ozone mass deficit}

As in Bodeker and Scourfield (1995), the Antarctic vortex period (AVP; day 200-335; 19 July-1 December) mean ozone mass deficit has been calculated for each year and is plotted together with an estimate of the EEASC in Fig. 1. The mass deficit quantifies the mass of ozone that would need to be added to the atmosphere to return TCO values over Antarctica to above $220 \mathrm{DU}(1 \mathrm{DU}=2.69 \times$ $10^{16}$ molecules $/ \mathrm{cm}^{2}$ ). The scale for the EEASC curve (right $y$ axis) is obtained from fitting the AVP mean ozone mass deficit to EEASC over the period 1979 to 2000, just before EEASC peaks. The fact that after 2000 more of the data points fall below the EEASC curve than above it suggests that factors other than the decline in halogen loading of the Antarctic stratosphere are driving the return of the Antarctic ozone layer to pre-1980 levels.

Weber et al. (2011) showed that interannual variability in the severity of Antarctic ozone depletion is explained well by the $100 \mathrm{hPa}$ winter eddy heat flux, suggesting that an increase in eddy heat flux in the first two decades of the 21st century, compared to the last two decades of the 20th century, would partially explain the anomalously smaller AVP mean ozone mass deficit after 2000. More recently, Chemke and Polvani (2020) used reanalysis and global climate model data to show that in the Southern Hemisphere the eddy heat flux has robustly strengthened, relative to the 1979-1989 period. They link this strengthening to the recent multi-decadal cooling of Southern Ocean surface temperatures. As presented in Xia et al. (2020), eddy heat fluxes derived from ERA Interim data are elevated post-2000 compared to before 2000 in September and October, resulting in higher stratospheric temperatures and thereby lower ozone depletion.

The anomalously low AVP mean ozone mass deficits in 1988, 2002, and 2019 all result from sudden stratospheric warmings (SSWs), large in 1988 (Kanzawa and Kawaguchi, 1990), major in 2002 (Newman and Nash, 2005), and minor in 2019 (Wargan et al., 2020), that elevated Antarctic stratospheric temperatures and curtailed the heterogeneous chemical processes driving polar ozone destruction. The SSW in 1988 led to an Antarctic ozone hole that was shallow in depth and small in area (Kanzawa and Kawaguchi, 1990; Schoeberl et al., 1989; Krueger et al., 1989). In 2002, unusually large planetary wave activity caused a major SSW that weakened and warmed the polar vortex and resulted in reduced ozone depletion over Antarctica (Allen et al., 2003; Glatthor et al., 2004; Konopka et al., 2005; Manney et al., 2005; Ricaud et al., 2005). The minor SSW in September 2019 resulted in significantly higher than usual polar TCO (Wargan et al., 2020; Safieddine et al., 2020) and the much reduced AVP mean ozone mass deficit in that year, smaller than in 2002 $\left(4.43_{-0.65}^{+0.96} \times 10^{9} \mathrm{~kg}\right.$ in $2002 \mathrm{cf} .2 .32_{-0.48}^{+0.89} \times 10^{9} \mathrm{~kg}$ in 2019). The large difference in the severity of Antarctic ozone deple- 


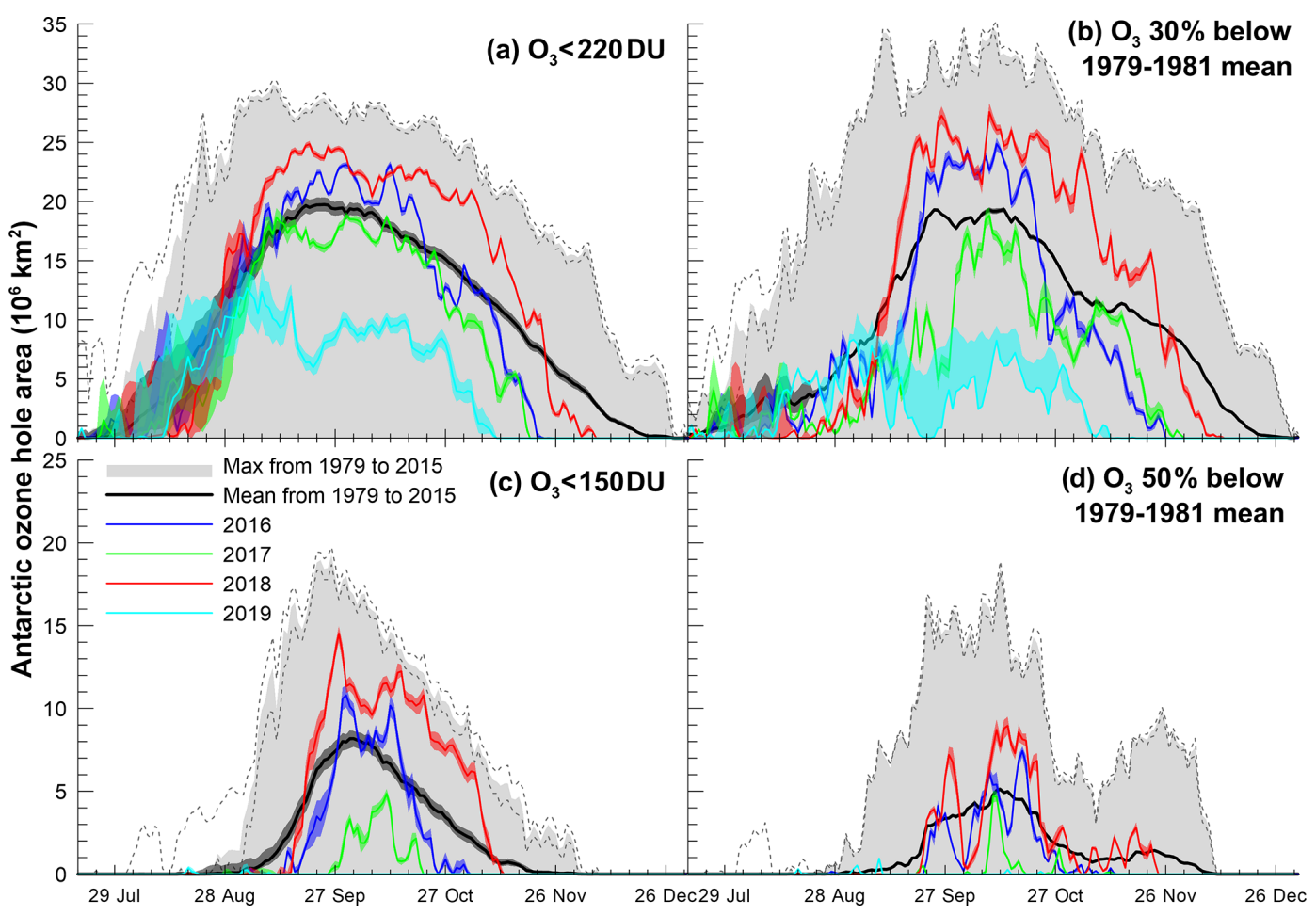

Figure 2. Daily measures of the size of the Antarctic ozone hole using four different criteria. Values for 2016 (blue), 2017 (green), 2018 (red), and 2019 (cyan) are compared against the range of values over the period 1979-2015 (greyed area). Dashed lines show $\pm 1 \sigma$ uncertainties on the 1979-2015 maxima. The mean ozone hole area over the period 1979 to 2015 is shown using a thick black line in all four panels. Coloured shaded regions around each trace indicate $\pm 1 \sigma$ uncertainties.

tion in 2018 and 2019 was found by Wargan et al. (2020) to result from (i) the geometry of the 2019 vortex, with ozonerich middle-stratospheric air masses overlying the lower portion of the vortex, and (ii) significantly reduced vortex volume.

The smaller-than-expected ozone holes in 1988, 2002, and 2019 (as well as other years when the stratosphere was anomalously warm) should not be interpreted as the Antarctic ozone layer recovering from the effects of ODSs faster than expected (Safieddine et al., 2020).

\section{Antarctic ozone hole area}

Daily measures of the Antarctic ozone hole area, defined using the four criteria listed above, for the most recent 4 years (2016-2019) are shown in Fig. 2 in the context of the mean and maximum over the period 1979 to 2015. For two of the metrics (TCO less than $150 \mathrm{DU}$ and TCO $50 \%$ or more below the 1979-1981 climatology) the 2019 ozone hole is essentially absent. Early in the season, e.g. before the end of August, the uncertainties on the calculated ozone hole areas are larger than later in the season as a result of the large uncertainties in the filling of the TCO fields during polar darkness. Uncertainties are also larger when the TCO in a cell identified as an ozone hole grid cell is very close to the threshold (such as in 2019 using the TCO $30 \%$ or more below the 1979-1981 climatology threshold). A small reduction in TCO values can result in a large increase in the region identified as being depleted in ozone. Other than under these circumstances, the uncertainties on the ozone hole areas appear small, suggesting that the area metric is robust against uncertainties in the underlying TCO fields. The significant differences between the 2018 and 2019 Antarctic ozone holes have been discussed extensively by Wargan et al. (2020). The source of the local minima in late October/early November in the time series for TCO $50 \%$ or more below the 1979-1981 mean is discussed in Bodeker et al. (2005).

Annual maximum ozone hole areas, and the dates on which they occur, are shown for all four threshold conditions in Fig. 3. The annual maxima in the daily values of the Antarctic ozone hole areas for the four ozone hole area criteria peak around the turn of the century, close to when EEASC peaks (see Fig. 1). EEASC explains between $47 \%$ and $73 \%$ of the variance in these ozone hole area time series. In contrast, the date when the maximum occurs shows a steady drift towards earlier dates over the 41-year period (linear trends equivalent to changes of between 15 and $19 \mathrm{~d}$ earlier, depending on metric). The cause of this drift towards consistently earlier dates of annual maximum ozone hole area has not been diagnosed here; correlation against EEASC indi- 


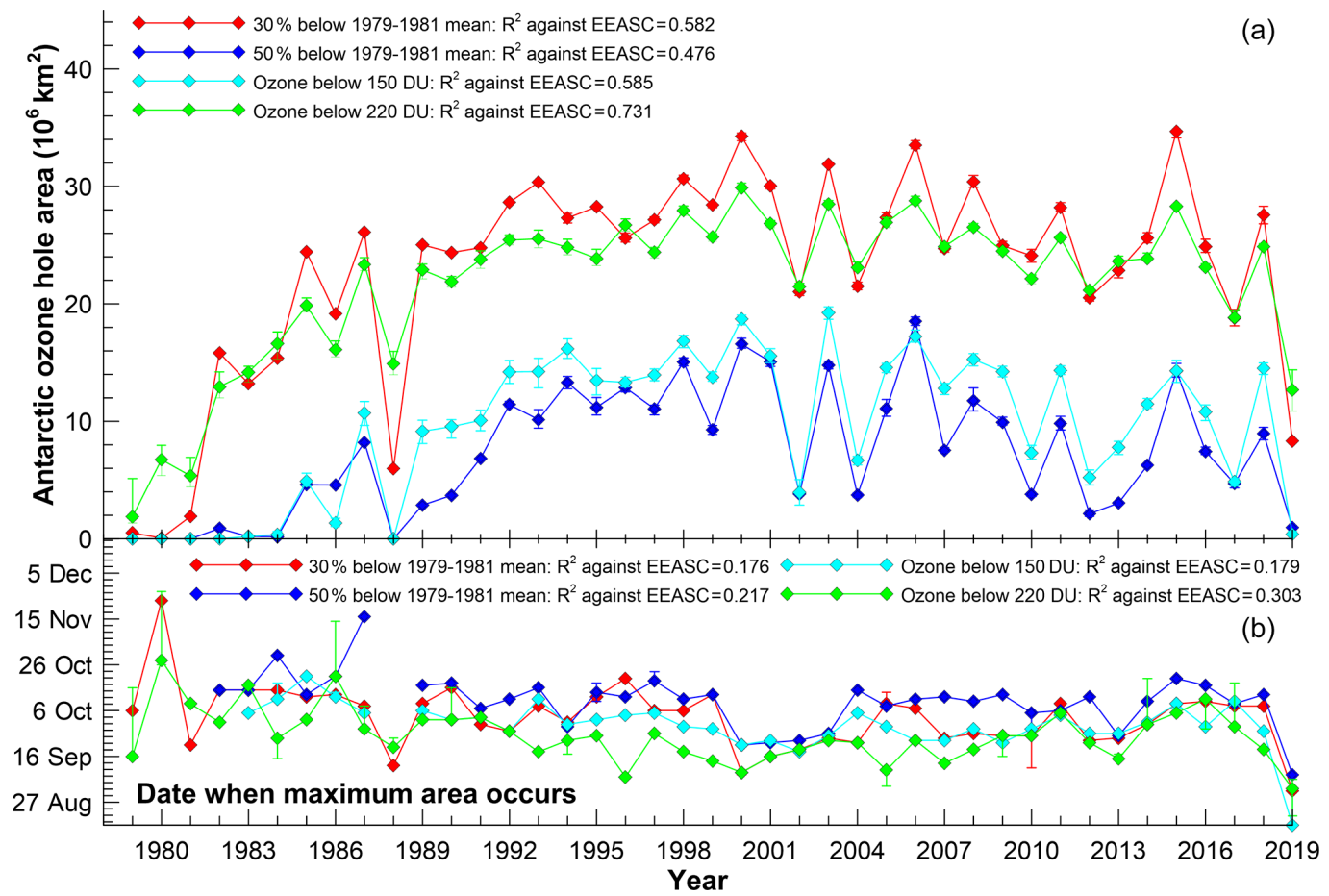

Figure 3. The annual maximum ozone hole area for the four different threshold criteria (a), and the dates on which those maxima were achieved (b). Error bars show $1 \sigma$ uncertainties, which are often asymmetrical. The $R^{2}$ values show the correlation coefficient between each of the time series and EEASC for the years when metrics are available.

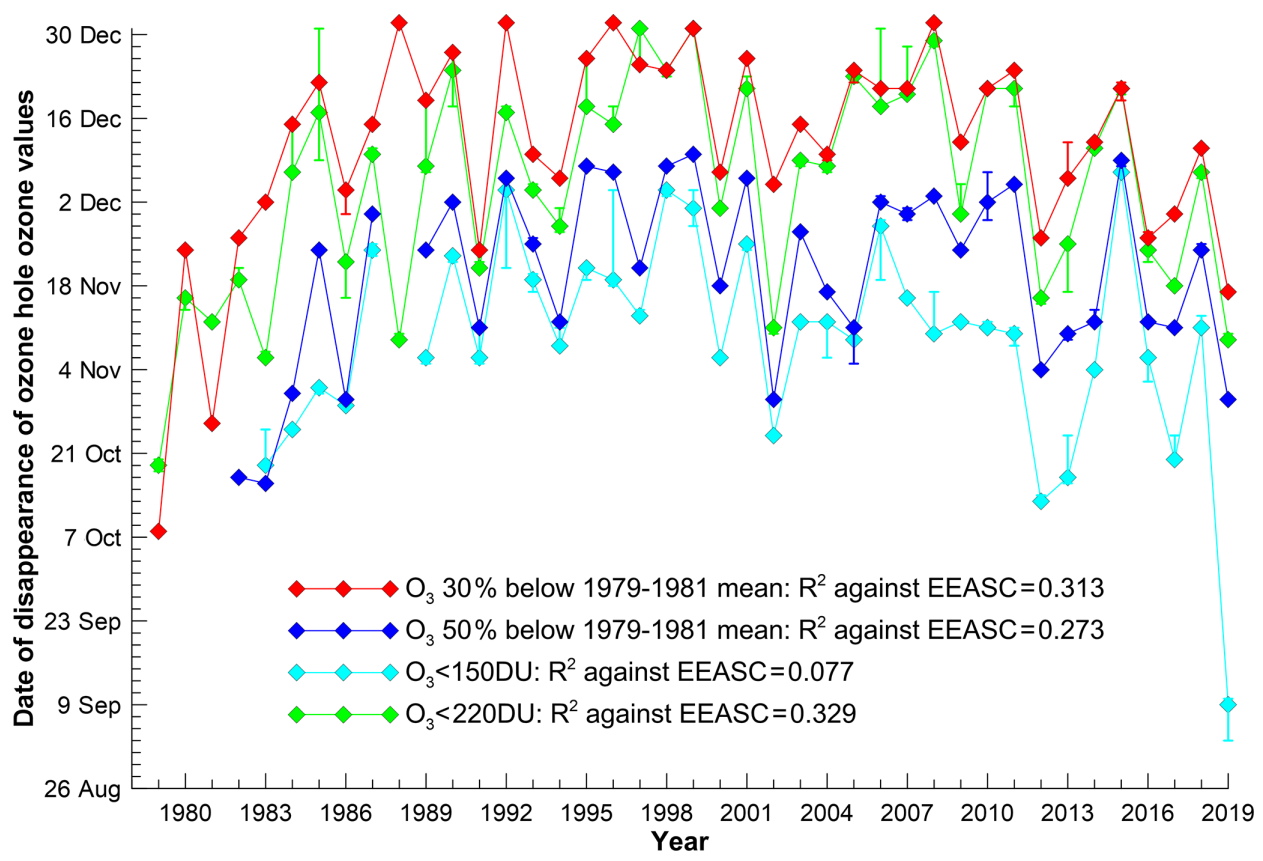

Figure 4. The annual dates of disappearance of ozone hole type values for all four threshold criteria. In some years the threshold for being identified as an ozone hole type value is not reached. The $R^{2}$ values show the correlation coefficient between each of the time series and EEASC for the years when disappearance dates are available. 


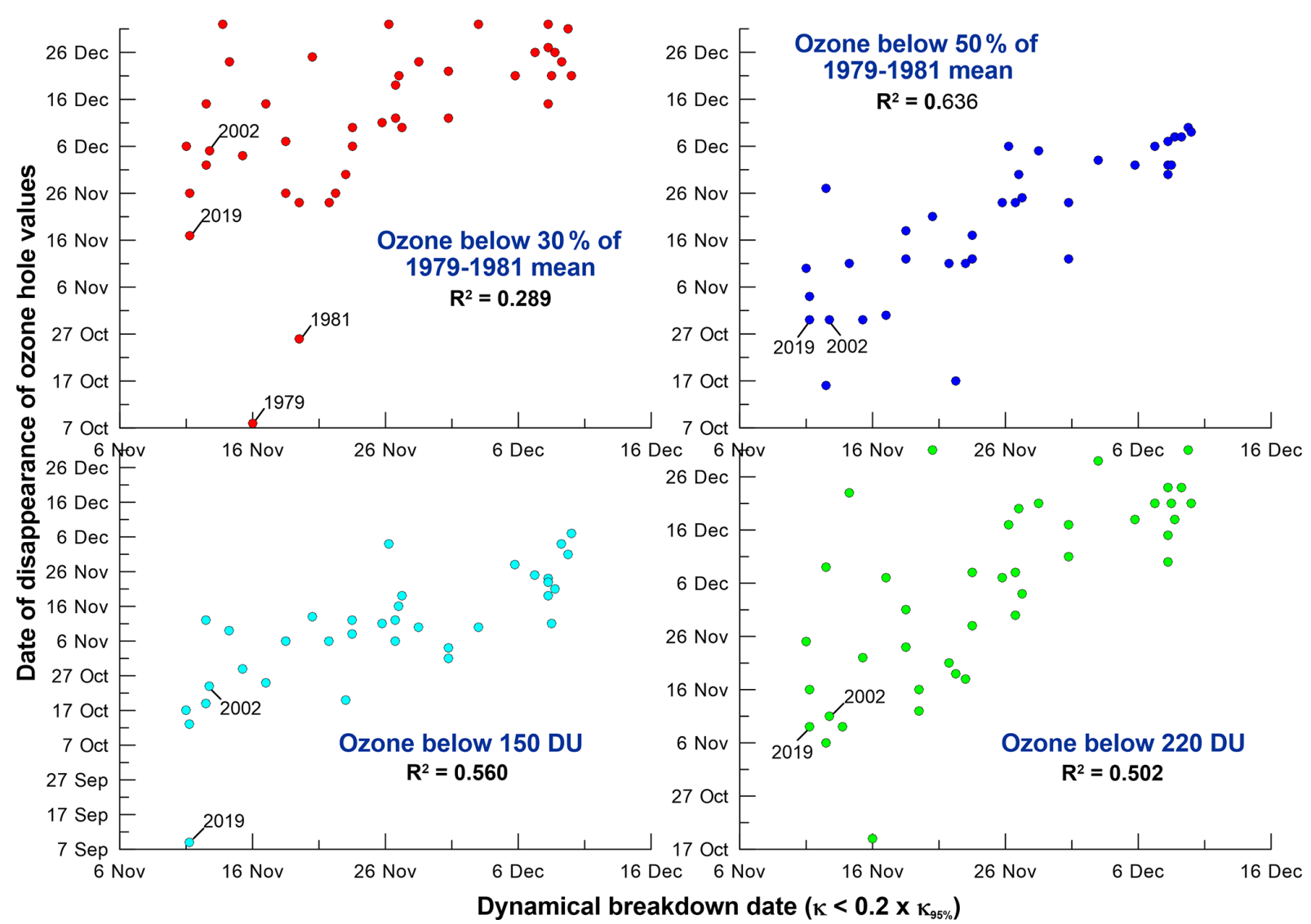

Figure 5. The annual dates of disappearance of ozone hole type values for all four threshold criteria plotted against the annual date of the breakdown of the dynamical vortex. $R^{2}$ values for linear fits to the data plotted in each panel are also shown.

cates that EEASC is not a strong predictor of the date when the maximum area occurs. The error bars, which are often asymmetric, are generally small.

The dates of disappearance of TCO values flagged as being within the Antarctic ozone hole by the four different criteria are shown in Fig. 4. After drifting to later in the year over the first 1.5 decades of the data series, since the early to mid1990s the dates of disappearance of ozone hole type values appear to have drifted to earlier in the year. However, this structure in the change of disappearance date before and after the turn of the century shows only weak correlation with EEASC $\left(0.077<R^{2}<0.329\right)$.

As in Bodeker et al. (2005), we have considered to what extent earlier breakdown of the dynamical vortex in recent years may have contributed to the date of disappearance of ozone hole type values coming earlier in recent years. To that end we have calculated 6-hourly profiles of the $550 \mathrm{~K}$ meridional impermeability $(\kappa)$ against equivalent latitude (Bodeker et al., 2002) from the NCEP-CFSv2 (the National Centers for Environmental Prediction Climate Forecast System Version 2, Saha et al., 2014) reanalyses for the period 1979 to 2019. For each year, 1460 meridional maximum $\kappa$ values were extracted (noting the 6-hourly frequency of the reanal- yses), hereafter $\kappa_{\text {max }}$-day. The date each year when $\kappa_{\text {max }}$-day falls below $20 \%$ of the 95th percentile of $\kappa_{\text {max-day }}$ is then identified as the date of the breakdown of the dynamical vortex. The annual dates of disappearance of ozone hole type values for the four different criteria are plotted against the dynamical vortex breakdown dates in Fig. 5. Except for the criterion of TCO being $30 \%$ or more below the 1979 to 1981 mean, the date of the dynamical breakdown of the Antarctic polar vortex explains more than half of the variance in the dates when ozone hole type values disappear. Furthermore, for 2002 and 2019 when a major SSW and a minor stratospheric warming occurred, respectively, both the dates on which ozone hole type values disappeared and the dates when the dynamical vortex broke down were earlier than in most other years (see labels on Fig. 5).

\section{Polar cap means}

While some previous studies have reported on annual minimum TCO values within the Antarctic vortex as a metric for tracking Antarctic ozone depletion (including Bodeker et al., 2005), Müller et al. (2008) showed that the utility of examining the minimum in daily TCO poleward of a threshold 


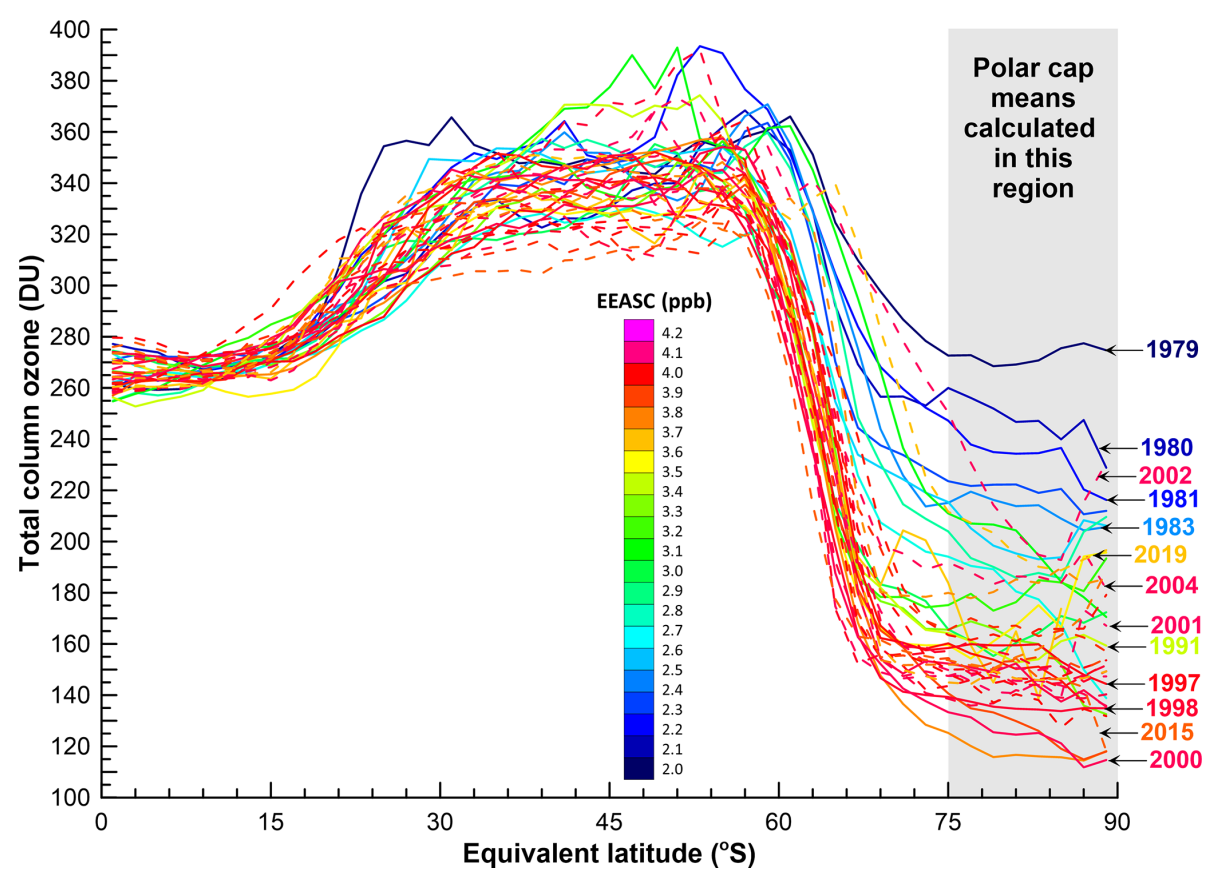

Figure 6. Zonal mean TCO profiles by equivalent latitude calculated on the $550 \mathrm{~K}$ surface for 1 October of each year. Each trace is coloured by equivalent effective Antarctic stratospheric chlorine (EEASC) shown in the colour-scale insert in the figure. Solid lines show data for the period 1979-2000, while dashed lines show data for the period thereafter. Uncertainties have been excluded from these traces for clarity but are generally very small (i.e. less than $5 \mathrm{DU}$ at this time of the year).

latitude was debatable, insofar as it relies on a single measurement. Müller et al. (2008) found that, for Arctic conditions, the minimum value often occurs in air outside the polar vortex, both in the observations and in a chemistryclimate model, and that the minimum value does not show a good correlation with chemical ozone loss in the vortex deduced from observations. They recommended that the minima, relying on a single measurement, should not be used as a metric of polar ozone depletion. Following that recommendation, we consider rather daily TCO zonal means calculated against equivalent latitude on the $550 \mathrm{~K}$ surface (Bodeker et al., 2001b). Examples of such zonal mean TCO profiles by equivalent latitude for 1 October of each year are shown in Fig. 6. The meridional profiles by equivalent latitude are characterized by very steep gradients across the dynamical polar vortex edge, typically around $62^{\circ} \mathrm{S}$ equivalent latitude (Bodeker et al., 2002), and very shallow gradients through the core of the dynamical vortex poleward of $75^{\circ} \mathrm{S}$ equivalent latitude. It is for this reason that polar cap TCO means are calculated in this region (see below). Some years, such as 2002, 2004, and 2019, show meridional profiles of zonal means much higher than would be expected from the EEASC loading at that time for the reasons outlined above.

Polar cap means (mean of TCO poleward of $75^{\circ} \mathrm{S}$ equivalent latitude) have been calculated for each day, and the daily time series for 2016 to 2019 are plotted in the context of the range and mean from 1979 to 2015 in Fig. 7. Uncertainties on the polar cap means are larger during the winter period where the uncertainties on the filled fields are larger. By mid- to late August, the uncertainties on the source TCO fields have only a very small effect on the uncertainties on the calculated polar cap means. The effects of the minor stratospheric warming that occurred in September 2019 are clear in the elevated polar cap means during that period. In mid-October, the 2018 polar caps means came close to being record-low values for this time of the year.

Annual minima in the daily polar cap mean TCO time series, and the dates on which those minima occurred, are shown in Fig. 8. The values minimize around the turn of the century and show a small positive trend thereafter. The uncertainties on the annual minimum polar cap mean TCO are typically less than 5 DU from 1979 to 1995 and less than 2 DU thereafter. While EEASC explains more than $70 \%$ of the variance in the annual minimum polar cap mean TCO, it explains essentially none of the variance in the date on which that minimum occurs.

\section{Changes in the vertical distribution of ozone}

Using vertically resolved ozone concentration measurements obtained from the BSVertOzone database, partial columns in $1 \mathrm{~km}$ thick layers poleward of $75^{\circ} \mathrm{S}$ equivalent latitude were calculated for the period 1985 to 2019. Partial columns of $1 \mathrm{~km}$ vertical extent, centred on 12 to $21 \mathrm{~km}$ altitude, are shown for the Southern Hemisphere spring in Fig. 9. Again, 


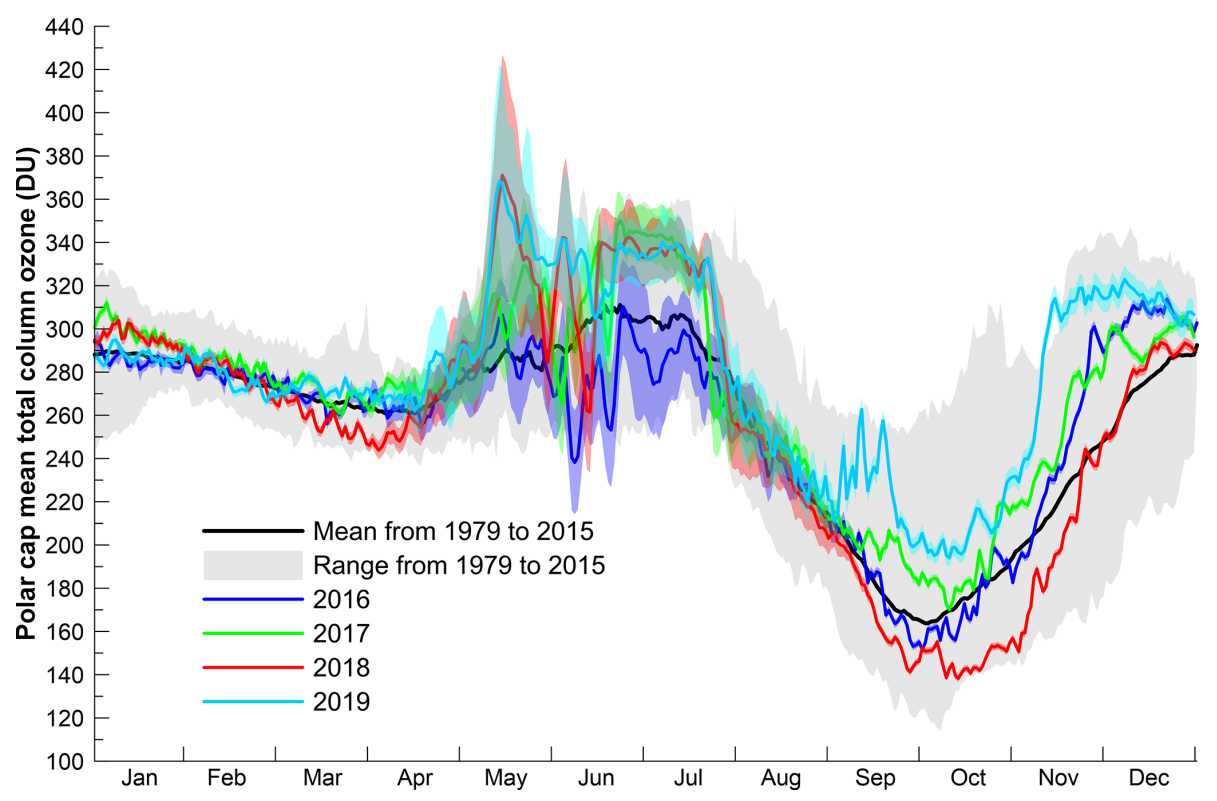

Figure 7. Daily polar cap average $\left(75^{\circ}\right.$ to $90^{\circ} \mathrm{S}$ equivalent latitude) total column ozone. The last 4 years of data are shown in the context of the 1979 to 2015 climatology. The shading around each trace indicates the $1 \sigma$ uncertainties.

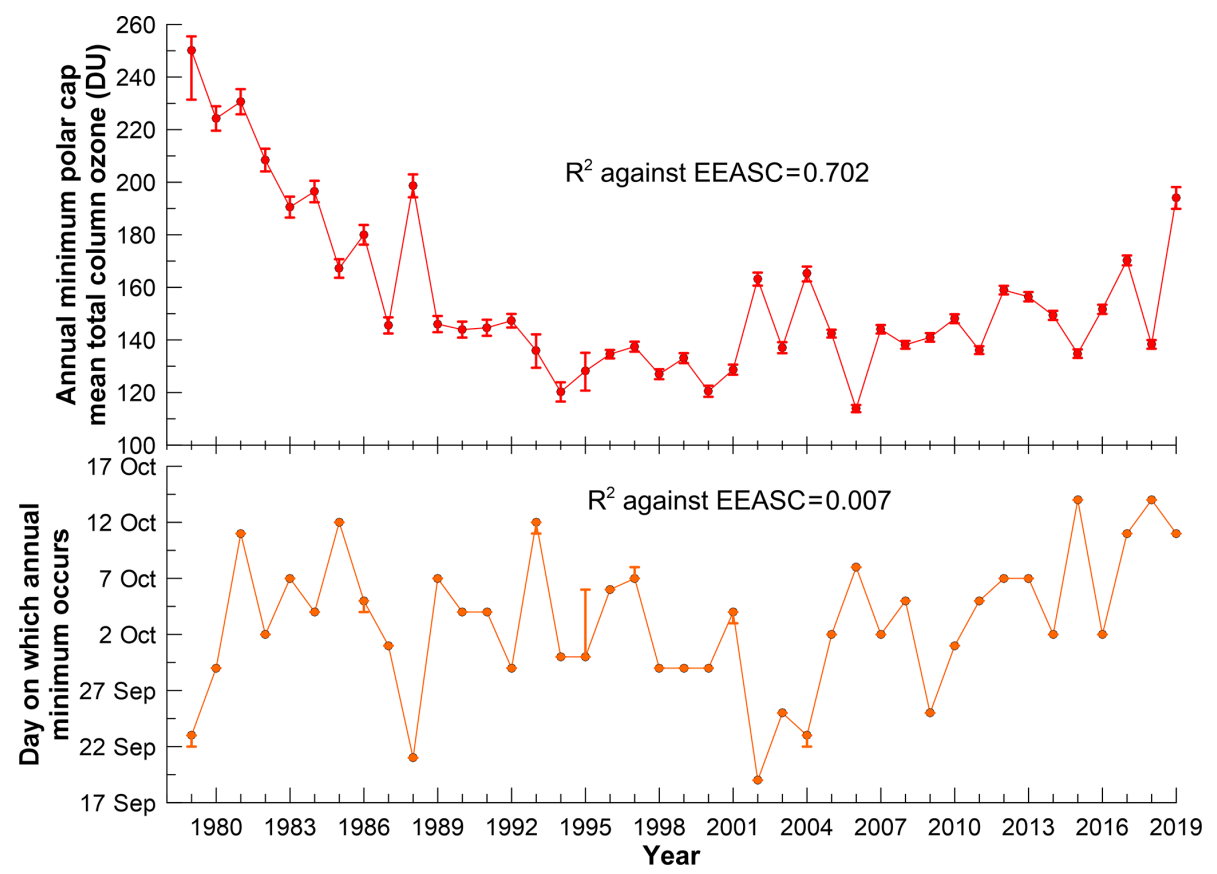

Figure 8. Annual minima in the daily polar cap mean TCO time series and the dates on which those minima occurred. Error bars show the $\pm 1 \sigma$ uncertainties, which are often asymmetrical.

the anomalous warm winters of 1988, 2002, and 2019 resulting in more ozone are clearly visible. Across all spring months partial ozone columns have increased since the late 1990s. The percentage contribution of each $1 \mathrm{~km}$ thick layer to the monthly mean, polar cap mean partial ozone column between 11.5 and $21.5 \mathrm{~km}$ is shown in Fig. 10. It is not clear whether the significant shifts in ozone between layers in
September in the mid-1990s result from sampling biases in the measurements available (noting the screening of SAGE-II data below $23 \mathrm{~km}$ in the few years following the Mt Pinatubo volcanic eruption in June 1991) or whether the vertical redistribution reflects a physical response to the eruption. During October and November the general sense is that from 1985 to around the turn of the century, ozone in the 11.5 and $21.5 \mathrm{~km}$ 


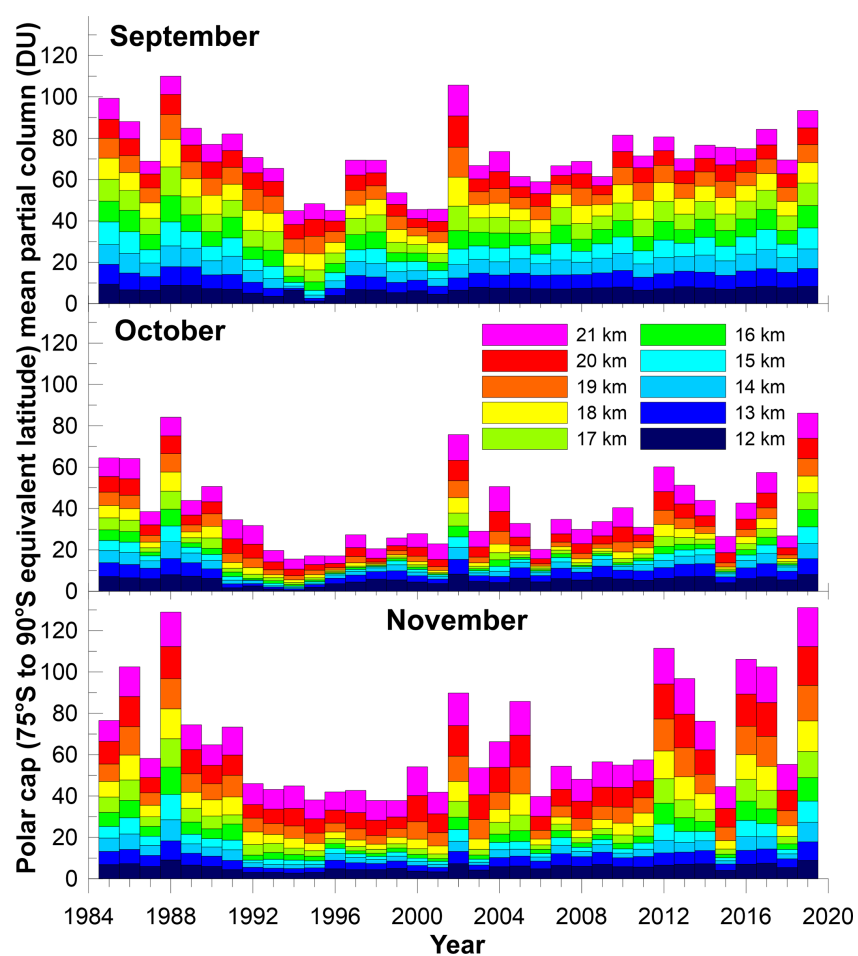

Figure 9. Monthly mean, polar cap mean $\left(75^{\circ}\right.$ to $90^{\circ} \mathrm{S}$ equivalent latitude), $1 \mathrm{~km}$ thick partial ozone columns for September, October, and November (Southern Hemisphere spring) of each year from 1985 to 2019.

column is concentrated more in the upper part of the column $(20$ to $21 \mathrm{~km})$ and less in the lower part of the column $(13$ to $18 \mathrm{~km})$ as a result of the heterogeneous chemistry in the Antarctic being most active between 16 and $18 \mathrm{~km}$ (Hofmann et al., 1987; Johnson et al., 1992). This trend reverses after the turn of the century, with ozone showing a more equitable distribution across the 10 layers by 2019 .

\section{Conclusions}

Several metrics describing the evolution of the Antarctic ozone hole over the 41-year period 1979 to 2019 are reported on above. These analyses were only possible through the availability of a complete, homogeneous climate data record of daily TCO fields. As detailed in Bodeker et al. (2020a), significant effort is required to homogenize the ozone fields from the 17 different space-based sensors measuring ozone that comprise the BS-filled TCO database, as well as to infer missing data through the polar night and in other regions where the operational parameters of the satellites result in data gaps. The requirements of the GCOS (Global Climate Observing System; GCOS-138, 2010; Bojinski et al., 2014) for climate data records, and in particular the need for all data to have traceable uncertainties, have led to the most recent versions of the NIWA-BS and BS-filled TCO databases

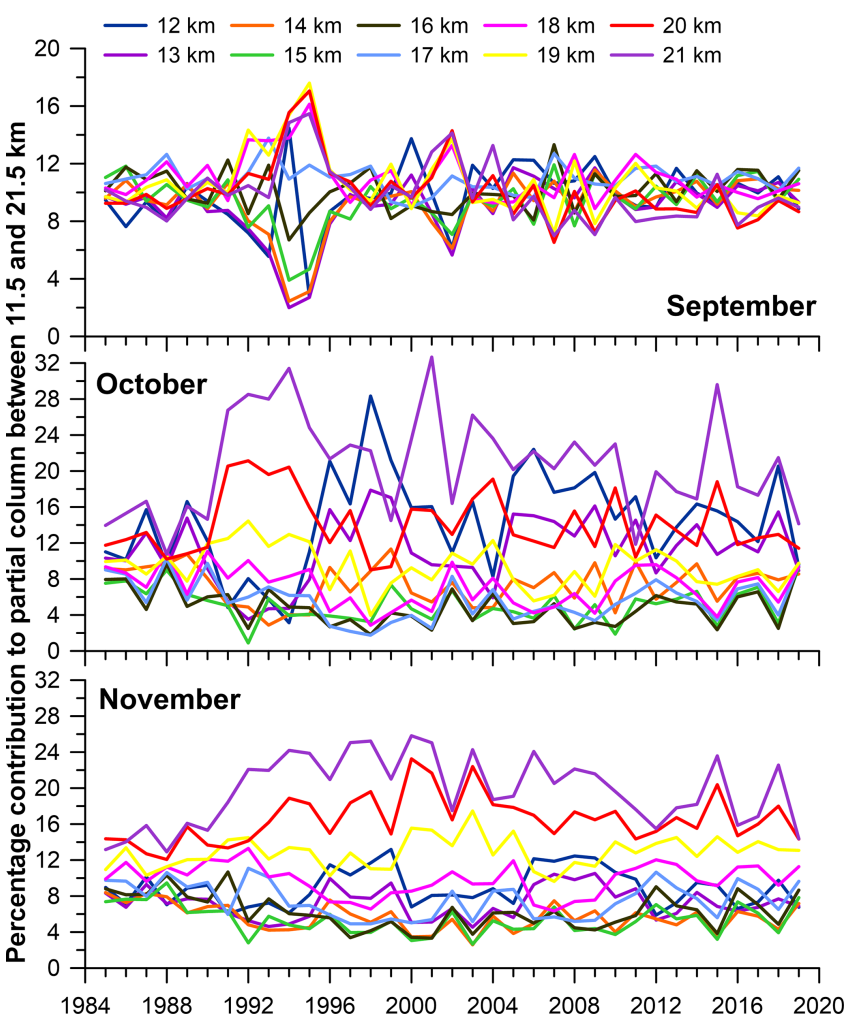

Figure 10. Percentage contribution of each $1 \mathrm{~km}$ thick layer to the monthly mean, polar cap mean $\left(75^{\circ}\right.$ to $90^{\circ} \mathrm{S}$ equivalent latitude), partial ozone column between 11.5 and $21.5 \mathrm{~km}$ for September, October, and November (Southern Hemisphere spring) of each year from 1985 to 2019 .

(V3.4 and V3.5.1) including estimates of the uncertainties on every TCO value as described in Bodeker et al. (2020a). This has allowed, for the first time, uncertainties to be included on the Antarctic ozone depletion metrics, showing which metrics are sensitive to uncertainties in the source TCO fields and which are not.

While a formal attribution of changes in the metrics shown above to changes in Antarctic stratospheric halogen loading has not been made and, as a result, statements about the recovery of the Antarctic ozone layer from the effects of ODSs cannot be made, all of the metrics directly related to ozone levels over Antarctica, i.e. AVP mean depleted mass, annual maximum ozone hole areas under four different criteria, the date when ozone hole type values disappear, annual minimum polar cap mean TCO, and polar cap mean ozone partial columns between 11.5 and $21.5 \mathrm{~km}$, all show changes consistent with decreasing Antarctic stratospheric halogen loading. The Antarctic ozone hole area defined by the $220 \mathrm{DU}$ contour shows the highest correlation against $\operatorname{EEASC}\left(R^{2}=0.731\right)$, suggesting that this measure of Antarctic ozone depletion may be the best to diagnose for indications of the recovery of the Antarctic ozone layer from the affects of ODSs. 
It is imperative that the networks of ground-based and space-based instruments required to monitor the global ozone layer are maintained, that global homogenized and quality-controlled TCO climate data records continue to be maintained, and that metrics of Antarctic ozone depletion continue to be updated so that the effectiveness of the Montreal Protocol and its amendments and adjustments in returning the Antarctic ozone layer to an unperturbed state can continue to be assessed by policymakers.

Data availability. The NIWA-BS TCO database (https://doi.org/10.5281/zenodo.1346424, Bodeker et al., 2018) and the BS-filled TCO database (https://doi.org/10.5281/zenodo.3908787, Bodeker et al., 2020b) are available from the zenodo archive. The vertically resolved ozone database (BSVertOzone) is also available on zenodo (Hassler et al., 2018b, https://doi.org/10.5281/zenodo.1217184). All databases are available for non-commercial purposes under the Creative Commons Attribution NonCommercial ShareAlike 4.0 International licence and are provided as netCDF files. The data underlying all of the plots in this paper can be obtained on emailing the lead author.

Author contributions. GEB wrote much of the code for processing the TCO data files into a common format and the code for creating the BS-filled TCO database, created several of the figures, and wrote much of the text of the paper. SK ran and debugged the code for applying the corrections to the 17 different TCO data sets, assisted with the writing of the paper, and created some of the figures. SK also created the vertically resolved ozone database used to create Figs. 9 and 10.

Competing interests. The authors declare no competing interest.

Acknowledgements. We acknowledge the World Meteorological Organization Global Atmosphere Watch (WMO/GAW) Ozone Monitoring Community and the World Ozone and Ultraviolet Radiation Data Centre (WOUDC) for the Dobson and Brewer TCO data, which were used to correct the space-based measurements used in this analysis. A list of all contributing sites is available on https://woudc.org/data/stations/ (last access: 30 March 2021). We would also like to thank the many satellite teams who provide their data freely to the ozone research community. Without access to these source data, the calculation of the Antarctic ozone depletion metrics presented here would not be possible.

Financial support. This research has been supported through funding from the New Zealand Ministry of Business, Innovation and Employment through the Antarctic Science Platform (ASP) (contract no. ANTA1801).
Review statement. This paper was edited by Jayanarayanan Kuttippurath and reviewed by two anonymous referees.

\section{References}

Allen, D. R., Bevilacqua, R. M., Nedoluha, G. E., Randall, C. E., and Manney, G. L.: Unusual stratospheric transport and mixing during the 2002 Antarctic winter, Geophys. Res. Lett., 30, 1599, https://doi.org/10.1029/2003GL017117, 2003.

Amos, M., Young, P. J., Hosking, J. S., Lamarque, J.-F., Abraham, N. L., Akiyoshi, H., Archibald, A. T., Bekki, S., Deushi, M., Jöckel, P., Kinnison, D., Kirner, O., Kunze, M., Marchand, M., Plummer, D. A., Saint-Martin, D., Sudo, K., Tilmes, S., and Yamashita, Y.: Projecting ozone hole recovery using an ensemble of chemistry-climate models weighted by model performance and independence, Atmos. Chem. Phys., 20, 9961-9977, https://doi.org/10.5194/acp-20-9961-2020, 2020.

Bodeker, G. E. and Scourfield, M. W. J.: Planetary waves in total ozone and their relation to Antarctic ozone depletion, Geophys. Res. Lett., 22, 2949-2952, 1995.

Bodeker, G. E., Connor, B. J., Liley, J. B., and Matthews, W. A.: The global mass of ozone: 1978-1998, Geophys. Res. Lett., 28, 2819-2822, 2001a.

Bodeker, G. E., Scott, J. C., Kreher, K., and McKenzie, R. L.: Global ozone trends in potential vorticity coordinates using TOMS and GOME intercompared against the Dobson network: 1978-1998, J. Geophys. Res., 106, 23029-23042, 2001 b.

Bodeker, G. E., Struthers, H., and Connor, B. J.: Dynamical containment of Antarctic ozone depletion, Geophys. Res. Lett., 29, 2-1-2-4, https://doi.org/10.1029/2001GL014206, 2002.

Bodeker, G. E., Shiona, H., and Eskes, H.: Indicators of Antarctic ozone depletion, Atmos. Chem. Phys., 5, 2603-2615, https://doi.org/10.5194/acp-5-2603-2005, 2005.

Bodeker, G. E., Nitzbon, J., Lewis, J., Schwertheim, A., Tradowsky, J. S., and Kremser, S.: NIWA-BS Total Column Ozone Database [Data Set], Zenodo, https://doi.org/10.5281/zenodo.1346424, 2018.

Bodeker, G. E., Nitzbon, J., Tradowsky, J. S., Kremser, S., Schwertheim, A., and Lewis, J.: A Global Total Column Ozone Climate Data Record, Earth Syst. Sci. Data Discuss. [preprint], https://doi.org/10.5194/essd-2020-218, in review, 2020a.

Bodeker, G. E., Kremser, S., and Tradowsky, J. S.: BS Filled Total Column Ozone Database [Data Set], Zenodo, https://doi.org/10.5281/zenodo.3908787, 2020b.

Bojinski, S., Verstraete, M., Peterson, T. C., Richter, C., Simmons, A., and Zemp, M.: The concept of essential climate variables in support of climate research, applications, and policy, B. Am. Meteorol. Soc., 95, 1432-1443, https://doi.org/10.1175/BAMS-D13-00047.1, 2014.

Chemke, R. and Polvani, L. M.: Linking midlatitudes eddy heat flux trends and polar amplification, npj Clim. Atmos. Sci., 3, 8, https://doi.org/10.1038/s41612-020-0111-7, 2020.

de Laat, A. T. J., van Weele, M., and van der A, R. J.: Onset of stratospheric ozone recovery in the Antarctic ozone hole in assimilated daily total ozone columns, J. Geophys. Res.-Atmos., 122, 11880-11899, https://doi.org/10.1002/2016JD025723, 2017.

Dhomse, S. S., Kinnison, D., Chipperfield, M. P., Salawitch, R. J., Cionni, I., Hegglin, M. I., Abraham, N. L., Akiyoshi, H., 
Archibald, A. T., Bednarz, E. M., Bekki, S., Braesicke, P., Butchart, N., Dameris, M., Deushi, M., Frith, S., Hardiman, S. C., Hassler, B., Horowitz, L. W., Hu, R.-M., Jöckel, P., Josse, B., Kirner, O., Kremser, S., Langematz, U., Lewis, J., Marchand, M., Lin, M., Mancini, E., Marécal, V., Michou, M., Morgenstern, O., O’Connor, F. M., Oman, L., Pitari, G., Plummer, D. A., Pyle, J. A., Revell, L. E., Rozanov, E., Schofield, R., Stenke, A., Stone, K., Sudo, K., Tilmes, S., Visioni, D., Yamashita, Y., and Zeng, G.: Estimates of ozone return dates from ChemistryClimate Model Initiative simulations, Atmos. Chem. Phys., 18, 8409-8438, https://doi.org/10.5194/acp-18-8409-2018, 2018.

Douglass, A., Fioletov, V., Godin-Beekmann, S., Müller, R., Stolarski, R. S., Webb, A., Arola, A., Burkholder, J. B., Burrows, J. P., Chipperfield, M. P., Cordero, R., David, C., den Outer, P. N., Diaz, S. B., Flynn, L. E., Hegglin, M., Herman, J. R., Huck, P., Janjai, S., Jánosi, I. M., Krzyścin, J. W., Liu, Y., Logan, J., Matthes, K., McKenzie, R. L., Muthama, N. J., Petropavlovskikh, I., Pitts, M., Ramachandran, S., Rex, M., Salawitch, R. J., Sinnhuber, B.-M., Staehelin, J., Strahan, S., Tourpali, K., Valverde-Canossa, J., and Vigouroux, C.: Stratospheric ozone and surface ultravioletradiation, Chapter 2, in: Scientific Assessment of Ozone Depletion: 2010, Global Ozone Res. Mon. Proj., Report No. 52, World Meteorological Organization, Geneva, Switzerland, 76 pp., available at: https://www.esrl.noaa. gov/cs1/assessments/ozone/2010/chapters/chapter2.pdf (last access: 15 October 2020), 2011.

Farman, J. C., Gardiner, B. G., and Shanklin, J. D.: Large losses of total ozone in Antarctica reveal seasonal $\mathrm{ClO}_{x} / \mathrm{NO}_{x}$ interaction, Nature, 315, 207-210, 1985.

GCOS-138: Implementation plan for the global observing system for climate in support of the UNFCCC, GOOS-184, GTOS-76, WMO-TD/No. 1523, available at: https://library.wmo.int/doc num.php?explnum_id=3851 (last access: 30 March 2021), World Meteorological Organization (WMO), 2010.

Glatthor, N., Von Clarmann, T., Fischer, H., Grabowski, U., Höpfner, M., Kellmann, S., Kiefer, M., Linden, A., Milz, M., Steck, T., Stiller, G. P., Tsidu, G. M., and Wang, D.Y.: Spaceborne $\mathrm{ClO}$ observations by the Michelson Interferometer for Passive Atmospheric Sounding (MIPAS) before and during the Antarctic major warming in September/October 2002, J. Geophys. Res.-Atmos., 109, D11307, https://doi.org/10.1029/2003JD004440, 2004.

Gonzalez, M., Taddonio, K. N., and Sherman, N. J.: The Montreal Protocol: how today's successes offer a pathway to the future, J. Environ. Stud. Sci., 5, 122-129, https://doi.org/10.1007/s13412014-0208-6, 2015.

Hassler, B., Kremser, S., Bodeker, G. E., Lewis, J., Nesbit, K., Davis, S. M., Chipperfield, M. P., Dhomse, S. S., and Dameris, M.: An updated version of a gap-free monthly mean zonal mean ozone database, Earth Syst. Sci. Data, 10, 1473-1490, https://doi.org/10.5194/essd-10-1473-2018, 2018a.

Hassler, B., Kremser, S., Bodeker, G., Lewis, J., Nesbit, K., Davis, S., Chipperfield, M., Dohmse, S., and Dameris, M.: BSVerticalOzone database (Version v1.0) [Data set], Zenodo, https://doi.org/10.5281/zenodo.1217184, 2018b.

Hofmann, D. J., Harder, J. W., Rolf, S. R., and Rosen, J. M.: Baloonborne observations of the development and vertical structure of the Antarctic ozone hole in 1986, Nature, 326, 59-62, 1987.
Huck, P. E., Tilmes, S., Bodeker, G. E., Randel, W. J., McDonald, A. J., and Nakajima, H.: An improved measure of ozone depletion in the Antarctic stratosphere, J. Geophys. Res., 112, D11104, https://doi.org/10.1029/2006JD007860, 2007.

Johnson, B. J., Deshler, T., and Thompson, R. A.: Vertical profiles of ozone at McMurdo station, Antarctica, spring 1991, Geophys. Res. Lett., 19, 1105-1108, 1992.

Kanzawa, H. and Kawaguchi, S.: Large stratospheric sudden warming in Antarctic late winter and shallow Ozone Hole in 1988, Geophys. Res. Lett., 17, 77-80, 1990.

Keeble, J., Brown, H., Abraham, N. L., Harris, N. R. P., and Pyle, J. A.: On ozone trend detection: using coupled chemistryclimate simulations to investigate early signs of total column ozone recovery, Atmos. Chem. Phys., 18, 7625-7637, https://doi.org/10.5194/acp-18-7625-2018, 2018.

Konopka, P., Grooß, J.-U., Hoppel, K. W., Steinhorst, H.-M., and Müller, R.: Mixing and Chemical Ozone Loss during and after the Antarctic Polar Vortex Major Warming in September 2002, J. Atmos. Sci., 62, 848-859, 2005.

Krueger, A. J., Stolarski, R. S., and Schoeberl, M. R.: Formation of the 1988 Antarctic ozone hole, Geophys. Res. Lett., 16, 381-384, 1989.

Krzyścin, J. W., Jaroslawski, J., and Rajewska-Więch, B.: Beginning of the ozone recovery over Europe? - Analysis of the total ozone data from the ground-based observations, 1964-2004, Ann. Geophys., 23, 1685-1695, https://doi.org/10.5194/angeo23-1685-2005, 2005.

Kuttippurath, J., Lefèvre, F., Pommereau, J.-P., Roscoe, H. K., Goutail, F., Pazmiño, A., and Shanklin, J. D.: Antarctic ozone loss in 1979-2010: first sign of ozone recovery, Atmos. Chem. Phys., 13, 1625-1635, https://doi.org/10.5194/acp-131625-2013, 2013.

Manney, G. L., Sabutis, J. L., Allen, D. R., Lahoz, W. A., Scaife, A. A., Randall, C. E., Pawson, S., Naujokat, B., and Swinbank, R.: Simulations of Dynamics and Transport during the September 2002 Antarctic Major Warming, J. Atmos. Sci., 62, 690-707, 2005.

McKenzie, R., Bernhard, G., Liley, B., Disterhoft, P., Rhodes, S., Bais, A., Morgenstern, O., Newman, P., Oman, L., Brogniez, C., and Simic, S.: Success of Montreal Protocol Demonstrated by Comparing High-Quality UV Measurements with "World Avoided" Calculations from Two Chemistry-Climate Models, Sci. Rep.-UK, 9, 12332, https://doi.org/10.1038/s41598-01948625-z, 2019.

Müller, R., Grooß, J.-U., Lemmen, C., Heinze, D., Dameris, M., and Bodeker, G.: Simple measures of ozone depletion in the polar stratosphere, Atmos. Chem. Phys., 8, 251-264, https://doi.org/10.5194/acp-8-251-2008, 2008.

Newman, P. A. and Nash, E. R.: Quantifying the wave driving of the stratosphere, J. Geophys. Res., 105, 12485-12497, 2000.

Newman, P. A. and Nash, E. R.: The Unusual Southern Hemisphere Stratosphere Winter of 2002, J. Atmos. Sci., 62, 614-628, https://doi.org/10.1175/JAS-3323.1, 2005.

Newman, P. A., Kawa, S. R., and Nash, E. R.: On the size of the Antarctic ozone hole, Geophys. Res. Lett., 31, L21104, https://doi.org/10.1029/2004GL020596, 2004.

Newman, P. A., Nash, E. R., Kawa, S. R., Montzka, S. A., and Schauffler, S. M.: When will the Antarctic 
ozone hole recover?, Geophys. Res. Lett., 33, L12814, https://doi.org/10.1029/2005GL025232, 2006.

Newman, P. A., Oman, L. D., Douglass, A. R., Fleming, E. L., Frith, S. M., Hurwitz, M. M., Kawa, S. R., Jackman, C. H., Krotkov, N. A., Nash, E. R., Nielsen, J. E., Pawson, S., Stolarski, R. S., and Velders, G. J. M.: What would have happened to the ozone layer if chlorofluorocarbons (CFCs) had not been regulated?, Atmos. Chem. Phys., 9, 2113-2128, https://doi.org/10.5194/acp-9-21132009, 2009.

Ricaud, P., Lefèvre, F., Berthet, G., Murtagh, D., Llewellyn, E. J., Mégie, G., Kyrölä, E., Leppelmeier, G. W., Auvinen, H., Boonne, C., Brohede, S., Degenstein, D. A., de La Noë, J., Dupuy, E., El Amraoui, L., Eriksson, P., Evans, W. F. J., Frisk, U., Gattinger, R. L., Girod, F., Haley, C. S., Hassinen, S., Hauchecorne, A., Jimenez, C., Kyrö, E., Lautié, N., Le Flochmoën, E., Lloyd, N. D., McConnell, J. C., McDade, I. C., Nordh, L., Olberg, M., Pazmino, A., Petelina, S. V., Sandqvist, A., Seppälä, A., Sioris, C. E., Solheim, B. H., Stegman, J., Strong, K., Taalas, P., Urban, J., von Savigny, C., von Scheele, F., and Witt, G.: Polar vortex evolution during the 2002 Antarctic major warming as observed by the Odin satellite, J. Geophys. Res., 110, D05302, https://doi.org/10.1029/2004JD005018, 2005.

Safieddine, S., Bouillon, M., Paracho, A. C., Jumelet, J., Tencé, F., Pazmino, A., Goutail, F., Wespes, C., Bekki, S., Boynard, A., Hadji-Lazaro, J., Coheur, P. F., Hurtmans, D., and Clerbaux, C.: Antarctic Ozone Enhancement During the 2019 Sudden Stratospheric Warming Event, Geophys. Res. Lett., 47, e2020GL087810, https://doi.org/10.1029/2020gl087810, 2020.

Saha, S., Moorthi, S., Wu, X., Wang, J., Nadiga, S., Tripp, P., Behringer, D., Hou, Y.-T., Chuang, H.-Y., Iredell, M., Ek, M., Meng, J., Yang, R., Mendez, M. P., van den Dool, H., Zhang, Q., Wang, W., Chen, M., and Becker, E.: The NCEP Climate Forecast System Version 2, J. Climate, 27, 2185-2208, https://doi.org/10.1175/jcli-d-12-00823.1, 2014.

Schoeberl, M. R., Stolarski, R. S., and Krueger, A. J.: The 1988 Antarctic ozone depletion: comparison with previous year depletions, Geophys. Res. Lett., 16, 377-380, 1989.

Schoeberl, M. R., Douglass, A. R., Randolph, S., Dessler, A. E., Newman, P. A., Stolarski, R. S., Roche, A. E., Waters, J. W., and Russell, J. M.: Development of the Antarctic ozone hole, J. Geophys. Res., 101, 20909-20924, 1996.
Solomon, S., Ivy, D. J., Kinnison, D., Mills, M. J., Neely, R. R., and Schmidt, A.: Emergence of healing in the Antarctic ozone layer, Science, 353, 269-274, , https://doi.org/10.1126/science.aae0061, 2016.

Struthers, H., Bodeker, G. E., Austin, J., Bekki, S., Cionni, I., Dameris, M., Giorgetta, M. A., Grewe, V., Lefèvre, F., Lott, F., Manzini, E., Peter, T., Rozanov, E., and Schraner, M.: The simulation of the Antarctic ozone hole by chemistry-climate models, Atmos. Chem. Phys., 9, 6363-6376, https://doi.org/10.5194/acp9-6363-2009, 2009

Tully, M. B., Krummel, P. B., and Klekociuk, A. R.: Trends in Antarctic ozone hole metrics 2001-2017, Journal of Southern Hemisphere Earth Systems Science, 69, 52-56, https://doi.org/10.1071/es19020, 2019.

Uchino, O., Bojkov, R., Balis, D. S., Akagi, K., Hayashi, M., and Kajihara, R.: Essential characteristics of the Antarctic-spring ozone decline: update to 1998, Geophys. Res. Lett., 26, 13771380, 1999.

Wargan, K., Weir, B., Manney, G. L., Cohn, S. E., and Livesey, N. J.: The anomalous 2019 Antarctic ozone hole in the GEOS Constituent Data Assimilation System with MLS observations, J. Geophys. Res.-Atmos., 125, e2020JD033335, https://doi.org/10.1029/2020JD033335, 2020.

Weber, M., Dikty, S., Burrows, J. P., Garny, H., Dameris, M., Kubin, A., Abalichin, J., and Langematz, U.: The Brewer-Dobson circulation and total ozone from seasonal to decadal time scales, Atmos. Chem. Phys., 11, 11221-11235, https://doi.org/10.5194/acp-11-11221-2011, 2011.

Xia, Y., Xu, W., Hu, Y., and Xie, F.: Southern-Hemisphere highlatitude stratospheric warming revisit, Clim. Dyn., 54, 16711682, https://doi.org/10.1007/s00382-019-05083-7, 2020.

Yang, E.-S., Cunnold, D. M., Newchurch, M. J., Salawitch, R. J., McCormick, M. P., Russell, J. M., Zawodny, J. M., and Oltmans, S. J.: First stage of Antarctic ozone recovery, J. Geophys. Res.Atmos., 113, D20308, https://doi.org/10.1029/2007JD009675, 2008. 